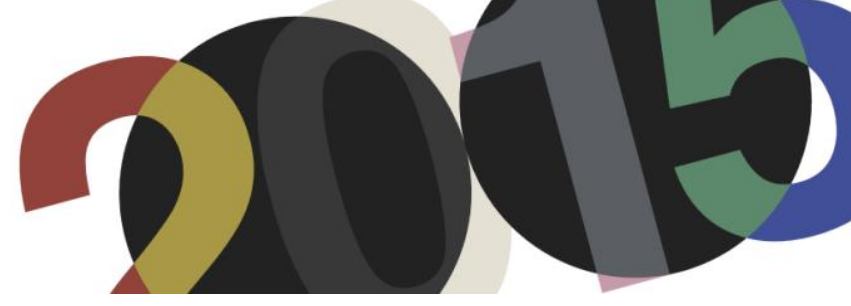

DOI: http://dx.doi.org/10.4995/LC2015.2015.928

\title{
All of Paris, Darkly: Le Corbusier's Beistegui Apartment, 1929-1931
}

\section{R. Anderson}

The University of Sydney

\begin{abstract}
This paper, All of Paris, Darkly, presents a focused study of Le Corbusier's enigmatic Beistegui Apartment (19291931) on the Champs-Elysée in Paris, with particular reference to the curious camera obscura periscope that was housed in a small lozenge-shaped pavilion on its rooftop. There are manifold reasons for the charisma of the apartment; from the flamboyant eccentricities of the client and his exchanges with the architect, to the exceptional location of apartment in the centre of Paris, to the apparent repudiation of some of Le Corbusier's more strident proclamations on architecture and the city, to the historical conditions that have for all time occluded a definitive scholarly reading of the architectural production and subsequent inhabitation of the apartment. Grounded in an understanding of the primal visual phenomenon of the camera obscura, the paper advances an interpretation of the meaning of the periscope apparatus amidst the battery of unusual contrivances that animated the surrealist penthouse apartment. It further seeks to contribute to a greater understanding of some aspects of Le Corbusier's thinking on architecture and the city.
\end{abstract}

Keywords: Le Corbusier; Charles de Beistegui; camera obscura; uncanny; Surrealism.

This paper, All of Paris, Darkly, presents a focused study of Le Corbusier's enigmatic Beistegui Apartment (1929-1931) on the 6th floor of 136 Avenue des Champs-Elysée in central Paris, with particular reference to the curious camera obscura periscope that was housed in a small lozenge-shaped pavilion on its roof top (fig. 1). Tim Benton has described the apartment as "one of the most exotic and puzzling of Le Corbusier's works" that can be seen to form a "coda and critique of the 1920s villas"1. It has also been suggested it was not so much a machine à habiter that Charles de Beistegui commissioned Le Corbusier to build as it was a machine à amuser ${ }^{2}$. There are manifold reasons for the charisma of the apartment; from the flamboyant eccentricities of the client and his exchanges with the architect, to the exceptional location of apartment in the centre of Paris, to the apparent repudiation of some of Le Corbusier's more strident proclamations on architecture and the city, to the historical conditions that have for all time occluded a definitive scholarly reading of the architectural production and subsequent inhabitation of the apartment.

There is a considerable body of literature that addresses the Beistegui Apartment in a substantial manner. Chief amongst these are, in chronological order, writings by Paolo Melis, Pierre Saddy, Manfredp Tafuri, Jacques Lucan, Bruno Reichlin, Beatriz Colomina, Sylvain Malfroy, Tim Benton, Wim van den Bergh, and Anthony Vidler $^{3}$. This paper assesses the texts critically, recognising that each has its own foci, merits and shortcomings.

\footnotetext{
${ }^{1}$ Tim Benton, The Villas of Le Corbusier 1920-1930, Basel: Birkhäuser, 2007, p. 203, p. 204.

${ }^{2}$ Wim van den Bergh, "Charles Beistegui: Autobiography and Patronage" OASE 83 Commissioning Architecture, December 2010, p. 17.

${ }^{3}$ Paolo Melis, "Il 'cadavere squisito' di Le Corbusier: Pierre Jeanneret e Charles Bestegui”, Controspazio 9, no. 3, 1977, pp. 36-37; Pierre Saddy, "Le Corbusier Chez Les Riches, L'appartement De Beistegui,” Architecture, Mouvement, Continuité 49, 1979, pp. 55-70; Manfredo Tafuri, "The City in the Work of Le Corbusier” in H. Allen Brooks, ed., Le Corbusier, Princeton, NJ: Princeton University Press, 1987, pp. 203-218; Jacques Lucan, Le Corbusier: une encyclopédie, Paris: Centre Georges Pompidou, 1987, pp. 68-71; Bruno Reichlin, “L’Esprit de Paris” Casabella, nos. 531-32, January-February 1987, p. 50; Beatriz Colomina, “The Split Wall: Domestic Voyeurism” in Max Risselada, ed. Raumplan Versus Plan Libre, New York:
} 
It seeks to correct some inherited errors of fact, particularly in relation to the contents of the primary drawings by Le Corbusier ${ }^{4}$. It identifies, for example, that there is an axonometric drawing is in circulation that clearly depicts both the camera obscura periscope and the famous fireplace in the chambre à ciel ouvert. It is drawn in accord with the distinct series of 1:50 axonometric drawings that Le Corbusier produced during the course of the design of the Beistegui Apartment, and the implication is that it concludes the series. However, Le Corbusier did not actually produce such a drawing. Both the camera obscura periscope and the fireplace appeared late in the process of design and were only properly drafted in plan, elevation and section drawings ${ }^{5}$ (figs. 2, 3 and 4).

The client for the apartment, Charles de Beistegui, has been described as an eccentric multimillionaire with an extravagant personal style of excessive neoclassical eclecticism, who "seized every opportunity to throw parties and banquets in his many (self-decorated) residences ... with friends from aristocratic, moneyed and artistic circles" ". In early 1929 Beistegui determined to realise a décor de fête as a rite of entry to the circles of the Parisian haute bohème. He shortlisted a number of prominent Modernist architects who might help him to realise his aim, these being Gabriel Guevrekian, André Lurçat, and Le Corbusier with Pierre Jeanneret, ${ }^{7}$. Each was solicited to produce a proposition for the apartment depicted in a suite of orthographic drawings and in a single axonometric drawing at 1:50 scale, without the knowledge of the others. Together with an initial estimate of cost, the drawings were required by the beginning of June 1929. Le Corbusier was, somewhat surprisingly, awarded the commission in mid-July 1929. He must have been challenged, if not chastened, by the fact that Beistegui had apparently been more roused by the other two architects' proposals ${ }^{8}$, but his enthusiasm for the project was

Rizzoli, 1988, pp. 32-51; Sylvain Malfroy, "Der Aussenraum ist immer ein Innenraum [The Exterior is Always an Interior]," Werk, Bauen + Wohnen 81, 1994, pp 36-41; Benton, The Villas of Le Corbusier 1920-1930; van den Bergh, "Charles Beistegui: Autobiography and Patronage", pp. 17-40; Anthony Vidler, "Paris: Beistegui Apartment, Or Horizons Deferred" in Jean-Louis Cohen, ed., Le Corbusier: An Atlas of Modern Landscapes, New York: The Museum of Modern Art, 2013, pp. 274-79.

${ }^{4}$ The primary drawings by Le Corbusier that were consulted for this paper are those that were reproduced in H. Allen Brooks, ed. The Le Corbusier Archive, Vol VIII: Appartement de Beistegui, Cité Univérsitaire - Pavillon Suisse, Ville Radieuse, and Other Buildings and Projects, 1930, New York: Garland and Fondation Le Corbusier, 1982.

${ }^{5}$ This axonometric drawing appears in Reichlin, "L’Esprit de Paris", p. 50; van den Bergh, "Charles Beistegui: Autobiography and Patronage", p. 36; and in Benton, The Villas of Le Corbusier and Pierre Jeanneret 1920-1930, p. 208. Benton suggest that this drawing is "based upon drawings in the le Corbusier office, c. May 1930", identifying FLC 17490 as the source. FLC 17490 is a plan drawing at the terrace level and the camera obscura periscope is not even depicted on it. Note also that the plan drawing that Benton includes on the same page as the axonometric is also incorrectly labeled as having been based upon FLC 17490. Not only does it depict the camera obscura periscope, it is a roof plan rather than a plan at the terrace level. The plan drawing on which it was based must have been FLC 29863.

${ }^{6}$ van den Bergh, "Charles Beistegui: Autobiography and Patronage", p. 17. It is important to note here the contribution of the interior designer Emilio Terry, who furnished Beistegui's dwellings, including the Beistegui Apartment. See Pierre ArizzoliClémentel, Emilio Terry, 1890-1969: architecte et décorateur, Montreuil, France: Gourcuff Gradenigo, 2013.

${ }^{7}$ Note that Robert Mallet-Stevens was a conspicuous omission from this list. He had recently completed houses for some of Beistegui's friends, and was evidently considered to be no longer 'original'. One of these houses was the Villa Paul Poiret (1921-23) and the second was the Villa Noailles (1923-28). Both houses are worth mentioning in that they had common features that would also appear in the Beistegui Apartment, namely the concept of the chambre à ciel ouvert, and the way that the vertical access to the rooftop terrace culminated in a protuberant observation post from which one enjoyed a controlled view of the surrounding landscape.

${ }^{8}$ Whilst Le Corbusier's proposal of the $3^{\text {rd }}-4^{\text {th }}$ June 1929 had a 'classic simplicity' (see FLC 17431, 17434-5), Beistegui evidently enjoyed the surprising promenades of follies in both Guevrekian's and Lurçat's proposals, along which he would be able to lead his guests. Le Corbusier's final design owes much to the proposals of the other two architects, although it is to be noted that he did not unthinkingly adopt any elements from them. Rather, he creatively transfigured particular architectural moments. For example, Guevrekian's table tennis table was transformed first into a croquet court and finally into the famous chambre à ciel ouvert. Guevrekian's and Lurçat's proposals are reproduced in van den Bergh, "Charles Beistegui: Autobiography and Patronage", p. 31. 
evident. In a letter to Beistegui he enthusiastically referred to the project as a programme vedette (stellar program) that would offer a "solution to the roofs of Paris".

Whilst much discussion on the Beistegui Apartment has understandably been in reference to Surrealism ${ }^{10}$, it will likely be more profitable to speak more particularly of the 'modern fragment', as thoughtfully and expansively addressed by Dalibor Vesely. Vesely wrote of the "situational meaning of individual fragments", identifying that in the early development of collage the creative process depended on a few critical points of reference that were usually fragments of a familiar reality, which were transformed through a sequence of steps into a more complex configuration that opened up the metaphorical possibilities of sameness and difference in reference to the "context of a world opened up by the main theme" ". He identified the metaphoricity of fragment as being not only relevant in the domain of the arts, but also potentially as the progenitor of " $a$ new restorative power relevant to our culture as a whole" ${ }^{, 12}$.

Vesely asserted that Le Corbusier was the first architect to consistently use fragment as part of a positive vision, and that in his interiors "the juxtaposition of elements and the overall layering of space are motivated entirely by situational criteria" ${ }^{13}$. He made particular reference to the chambre à ciel ouvert atop the Beistegui Apartment, which is treated simultaneously as an open space and a closed interior: "The situation is open to a series of readings in which individual elements play the role of metaphorical fragments, revealing the situational character of the dwelling in the context of a room, city and nature ${ }^{\prime 14}$. Vesely identified that the tool that permits us to navigate through the potentially infinite "forest of symbols and indices" is analogy, which has the capacity to reveal the deep relations between distant realities that nevertheless share a common latent world, which is "where our imagination and its organizing power have their source" $"$. The chambre à ciel ouvert contrives a series of analogical relationships: between the Arc de Triomphe and an ornate fireplace, between tended grass and carpet, and between the ceiling of a room and the sky ${ }^{16}$ (fig. 5). Peter Carl has, on many occasions, recognised the fecundity of Le Corbusier's analogical imagination. Of relevance to the current discussion is his recognition that the English word Chimney harbours only a portion of the French la cheminée, which also "directly refers to the fireplace, the fireside and to the mantelpiece-and is therefore another term for foyer within Corbusian iconography"17. That is, there is a depth to the associations that transcends matters of form and iconography.

Whilst the remarkable chambre à ciel ouvert has understandably attracted the most scholarly attention, it is to be noted that the preparatory sequence of spatial situations that Le Corbusier contrived for Beistegui's guests to

\footnotetext{
${ }^{9}$ Le Corbusier, cited in Vidler, "Paris: Beistegui Apartment, Or Horizons Deferred", p. 275.

${ }^{10}$ See for example Alexander Gorlin, "The Ghost in the Machine: Surrealism in the Work of Le Corbusier", Perspecta 18, 1982, pp. 50-65

${ }^{11}$ Dalibor Vesely, "Architecture and the Ambiguity of Fragment" in Robin Middleton, ed., The Idea of the City, Cambridge, Mass.: MIT Press, 1996, p. 115.

${ }^{12}$ Ibid., p. 116.

${ }^{13}$ Ibid., p. 118. See also Vesely, "Surrealism, Myth and Modernity", AD Profiles 11, 1978, pp. 87-95; and Vesely, Architecture in the Age of Divided Representation: The Question of Creativity in the Shadow of Production, Cambridge, Mass.: MIT Press, 2004.

${ }^{14}$ Ibid., 118. Vesely was more buoyant about the genuine architectural contribution of the chambre à ciel ouvert than others have been. Benton wrote that, as completed, "this open room, with its lawn carpet and working fireplace, mocked the simple pleasures of the early schemes". Benton, The Villas of Le Corbusier and Pierre Jeanneret 1920-1930, p. 208.

${ }^{15}$ Vesely, "Architecture and the Ambiguity of Fragment”, p. 117.

${ }^{16}$ Note that Le Corbusier had often asserted his conviction that "the exterior is always an interior." See for example a subsection of the chapter "Architecture II: The Illusion of Plans" entitled 'The Exterior is Always an Interior' in Le Corbusier, Towards a New Architecture, trans. Frederick Etchells, London: J. Rodker, 1931, pp. 191-194.

${ }^{17}$ Peter Carl, “Le Corbusier's Penthouse in Paris, 24 Rue Nungesser-Et-coli,” Daidalos 28, June 1988, p. 72.
} 
arrive at the outdoor room comprises an equally rich medley of 'metaphorical fragments'. The sequence begins with the corkscrew-like spiral staircase that ascended from the large open entertainment room below (fig. 6). Architecturally, the spiral staircase was 'set adrift' in the entertainment room. It did not in any way nestle, accord, align or converse with any other elements of the architecture, and it touched the ground very tenuously. The dark-coloured treads were extremely narrow, and could certainly have only been ascended one person at a time. In all, the staircase had something of the character of a ladder that conceptually had either been temporarily set in place from the room below or cast down from the circular hole in the base of the camera obscura pavilion. Peter Carl wrote of the spiral staircase to the roof garden in Le Corbusier's own apartment in similar terms, identifying it thematically with the Jacob's ladder that was later published in the architect's Poésie sur Alger, 1950, which ascended from a region of water "to arrive at the meeting-point of sea-horizon and heavens" ${ }^{18}$. $\mathrm{He}$ further drew a comparison between Le Corbusier's Jacob's ladder and the well-known example from Robert Fludd's Utriusque Cosmi ... Historia [The Origin and Structure of the Cosmos], 1619, which depicts "an ascent from dark matter to luminous spirit, from sensus to verbum"19. Carl suggested that the spiral staircase in Le Corbusier's apartment was structured to allow the inhabitant to re-enact the eternal drama that he provisionally termed "an awakening to creativity" 20 . A vertical handrail served as the axis of revolution around which the spatial transformation was to be enacted: "One's left hand rises in a vertical line while the body performs a spiral ascent around it" ${ }^{21}$. An identical situation occurred in the Beistegui Apartment. The guest stepped up from the vast dark carpeted floor (conceptually a region of water), with their left hand on the central vertical handrail and ascended in a spiral to the camera obscura pavilion that served as a vestibule between the actual everyday city of Paris and the "rooftop fantasy" 22 of the city above.

At the top of the spiral staircase the guest arrived, singly, in the small and necessarily dark camera obscura pavilion $^{23}$ (fig. 4). While the decision to include the camera obscura periscope in the pavilion was very likely made after the plans for the apartment were agreed upon in June $1930^{24}$, and there is debate as to whether its presence is to be attributed to Le Corbusier or Beistegui ${ }^{25}$, it can be read as the transformed fulfilment of an ambition that was present in the original schemes by Guevrekian and Lurçat, but that, interestingly enough, did not appear in Le Corbusier's original scheme. The two architects had each included a sundial in an open belvedere on the rooftop, which can only have been in response to the brief supplied by Beistegui. A sundial 'apprehends' the fundamental universal condition of time. A camera obscura is similarly acquisitive. Latin for

\footnotetext{
${ }^{18}$ Ibid., p. 73.

${ }^{19}$ Ibid., p. 73. Carl identified that "the goal of such ascents is the attainment of the pneumatikos, the spiritual man reconciled with the cosmos."

${ }^{20}$ Ibid., p. 71.

${ }^{21}$ Ibid., p. 72.

${ }^{22}$ Vidler, "Paris: Beistegui Apartment, Or Horizons Deferred",p. 277.

${ }^{23}$ Vidler referred to the pavilion as "small oval cabin ... windowless hut", Benton as a "free-standing oval projection on the roof terrace" and Malfroy as "a little house (Häuschen)". Vidler, "Paris: Beistegui Apartment, Or Horizons Deferred", p. 277; Benton, The Villas of Le Corbusier and Pierre Jeanneret 1920-1930, p. 206; and Malfroy, "Der Aussenraum ist immer ein Innenraum," p. 40. Unless otherwise noted all translations from German are by the author.

24 "One of the causes of the extra cost [of the apartment] was the provision of immensely costly changes caused by the piercing of the concrete slabs in order to fit the revolving periscope with its tall chimney like protuberance (April-July 1932)." Benton, The Villas of Le Corbusier and Pierre Jeanneret 1920-1930, pp. 206-208. Vidler similarly noted that "The periscope seems to have been conceived at the very last minute-requiring the demolition of the already completed reinforced concrete roof to the spiral stair." Vidler, "Paris: Beistegui Apartment, Or Horizons Deferred", p. 277.

${ }^{25}$ Reichlin has suggested that although it is impossible to know whether the periscope can be attributed to Le Corbusier or Charles de Beistegui, it was more likely to be de Beistegui's invention, since its construction demanded many alterations to the spiral staircase. He concludes that in any case, "it is certainly an idea that came at the end [of the design process]." Reichlin, "L’Esprit de Paris", p. 56.
} 
'darkened chamber', a camera obscura is a pre-photographic optical instrument producing an exact yet inverted re-production of an external scene in a darkened room as light passes through a small aperture ${ }^{26}$. Whilst the principle was known in antiquity, having been mentioned by Aristotle and others, it was first properly articulated by the Italian polymath Giambattista della Porta in his Magia Naturalis, $1558^{27}$. He described the effect as very pleasant for "great men and scholars and ingenious persons to behold" 28 . The camera obscura is a dark, quiet and slow phenomenon, in part due to the physiological requirement of a period of time for the eyes to adjust to the abrupt change in illumination upon entering $\mathrm{it}^{29}$. The image slowly revealed in the small dark pavilion in the Beistegui Apartment was an acquired vista of Paris that took in the full living city, not only the four emblems of the "imperishable heritage" ${ }^{30}$ of Paris that were privileged in the chambre à ciel ouvert. The strangeness of this apparition of the city would have lent the interior of the diminutive camera obscura periscope cabin an aura of the uncanny, which is what Sigmund Freud defined as the simultaneously familiar and foreign ${ }^{31}$.

The German for uncanny, unheimlich, literally 'un-homely', is a much more evocative and accurate rendering of the notion. Freud wrote that the word heimlich is ambiguous since "on the one hand it means that which is familiar and congenial, and on the other, that which is concealed and kept out of sight... Thus heimlich is a word the meaning of which develops towards an ambivalence, until it finally coincides with its opposite, unheimlich" ${ }^{32}$. In this case, the unheimlich would have been engendered by the revelation that perhaps the room itself, autonomous of the architect or client's determination, enjoyed a secret intercourse with the 'other'-the city of Paris that it faced silently every day. The conditions of the room into which the scene is projected affects its reception, whether or not it is consciously manipulated or is simply left to stand in its unaltered state. So, whilst the images re-produced by cameras obscura are 'objective', that is, they are unmediated by technology, every installation is never merely receptive. It is, to some degree, transformative. The transformative context was, in the case of the Beistegui Apartment, a small lozenge-shaped pavilion within a specific building on the Champs-Elysée that was in turn tied-in to the particular historical and urban context of the city of Paris, which mattered so much to Le Corbusier, and to the Surrealists ${ }^{33}$.

Paris possessed, for Le Corbusier, an inimitable 'esprit' that was expressed architecturally in the distinctive profile of the horizon of the city. In a renowned sequence of drawings explaining his Plan Voisin of 1925, to an audience in Buenos Aires in 1929, the architect traced the historical development of this horizon in five steps:

\footnotetext{
${ }^{26}$ For a concise history of the camera obscura see John H. Hammond, The Camera Obscura, Bristol: Adam Hilger, 1981.

${ }^{27}$ Giambattista della Porta, Magia Naturalis, Naples: Cancer, 1558. Published in English as Natural Magick by John Baptista Porta, a Neapolitane: In Twenty Books: Wherein are Set Forth all the Riches and Delights of the Natural Sciences, London: Thomas Young \& Samuel Speed, 1658.

${ }^{28}$ Porta, Natural Magick, p. 364.

${ }^{29}$ As Porta wrote, "when men walk in the Sun, if they come into the dark, that affection continues, that we can see nothing, or very scantly; because the affection made by the light, is still in our eyes; and when that is gone by degrees, we see clearly in dark places." Porta, Natural Magick, p. 363.

${ }^{30}$ These architectural icons were the Arc de Triomphe, Sacré-Coeur, Notre Dame and the Eiffel Tower. See Le Corbusier, The City of Tomorrow [Urbanisme, 1924], trans. Frederick Etchells, Cambridge, Mass.: MIT Press, 1929, pp. $271,281$.

${ }^{31}$ Sigmund Freud, "Das Unheimliche", Imago, Bd. V., 1919. Published in English as "The "Uncanny"” in The Complete Psychological Works, Vol. XVII, London: Hogarth Press 1955, pp. 217-56. For recent treatments of the uncanny in contemporary architectural discourse see Vidler, The Architectural Uncanny, Cambridge, Mass.: MIT Press, 1992; and Vidler, "Fantasy, The Uncanny and Surrealist Theories of Architecture" Papers of Surrealism 1, Winter 2003.

${ }^{32}$ Freud, "The 'Uncanny", pp. 222-223.

${ }^{33}$ In 1929, the same year that Le Corbusier began working on the Beistegui Apartment, Walter Benjamin wrote that for the Surrealists, at the "centre of this world of things stands the most dreamed-of of their objects, the city of Paris itself." And further that for the Surrealists' Paris was "a little universe." Walter Benjamin, "Surrealism: The Last Snapshot of the European Intelligentsia" [Der Sürrealismus: Die letzte Momentaufnahme der europäischen Intelligenz, 1929] in One-Way Street, London: Verso, 1979, p. 231.
} 
beginning with the medieval city with its focal Notre Dame; the classical city with its Louvre; Neoclassical Paris with its Pantheon; modern Paris with its Arc de Triomphe, Basilique due Sacré Coeur, and the Eiffel Tower; and finally, the Paris of Le Corbusier's imagination-entirely redeveloped according to his Plan Voisin. It is this point that it is possible to address the ways that Le Corbusier 'staged' the city of Paris in the Beistegui Apartment. Peter Carl has recognised that the main effect of the contrivances on the rooftop of the apartment was to mask out all of Paris but certain cultural monuments, "a vision of Paris analogous to that of the Plan Voisin of 1925"34. Reichlin has also written that "what makes the roof garden [chambre à ciel ouvert] interesting is the way that Le Corbusier staged the city" ${ }^{35}$, and Sylvain Malfroy has noted that in the apartment the view of Paris was "transformed through a subtle staging, and the model for this staging, as invented by the theatre of the $19^{\text {th }}$ century, would appear to owe much to the typological schema of the panorama" 36 . This recognition prompts consideration of the relevance of Le Corbusier's Pavillon de l'Esprit Nouveau at the International Exposition of Modern Decorative and Industrial Arts of 1925 in Paris, to the Beistegui Apartment. The main pavilion was a full-scale prototype of an ideal urban apartment. An exhibition annex that comprised large twin exedra-like rooms was constructed as a counterpoint to this single dwelling (fig. 7). It hosted dioramas ${ }^{37}$ of two of Le Corbusier's comprehensive urban schemes - the ideal Ville Contemporaine [Contemporary City for Three Million Inhabitants], 1922, and the Plan Voisin, 1925, which proposed demolishing much of the centre of Paris. As Richard Difford noted in his focused study of the building, "in the case of the dioramas, the existing city, which surrounds the pavilion and which is the subject of Le Corbusier's criticism, is explicitly shut out in favour of the artificially simulated alternative" ${ }^{\prime 3}$. This echoed the nineteenth-century inclination for dioramas to depict the city in which they were actually situated, rather than exotic alternative locations, revealing a "desire to present the city back to itself" 39 . Sylvain Malfroy recognised that in Le Corbusier's hands "the panorama is made into an instrument of anticipation. The public is challenged to experience in a direct and unmediated way the likeliness of the architectonic and urban propositions, and in fact to partake in the happiness of a completely transformed world" ${ }^{\prime 4}$. There is a clear intention to coax, if not convert, the visitor to a point of view. As with the original nineteenth-century examples, there is a clear sense that the dioramas are "associated with mastery over the city and of collective space ${ }^{, 41}$.

The Beistegui Apartment was conceived 4 years after the Pavillon de l'Esprit Nouveau exhibition. Le Corbusier's hopes for the realisation of his hugely ambitious urban schemes can only have been tempered by that time. Vidler has put forward the hypothesis that the Beistegui Apartment was a "poignant response" to the refusal of his proposals, and that Le Corbusier may have sought to "create the illusion of a city erased", coupled with a "panoramic, didactic" view of the city, demanding its re-planning ${ }^{42}$. The role of the high-walled chambre à ciel ouvert was to judiciously remove from sight the "Pack-Donkey" streets of the everyday city, conferring

\footnotetext{
${ }^{34}$ Carl, "Le Corbusier's Penthouse", p. 67.

${ }^{35}$ Reichlin, "L’Esprit de Paris", p. 56.

${ }^{36}$ Malfroy, "Der Aussenraum ist immer ein Innenraum," p. 37.

${ }^{37}$ The word 'diorama' was coined in 1823 by the French photographer and scenographer Louis Daguerre. He fashioned the term from the Greek 'di-orama', to 'see through'. See Helmut and Alison Gernsheim, L. J. M. Daguerre: The History of the Diorama and the Daguerreotype, London: Secker \& Warburg, 1956, pp. 13-18.

${ }^{38}$ Richard Difford, "Infinite Horizons: Le Corbusier, the Pavilion De L'Esprit Nouveau Dioramas and the Science of Visual Distance," The Journal of Architecture 14:3, 2009, p. 304.

${ }^{39}$ Ibid., p. 304.

${ }^{40}$ Malfroy, "Der Aussenraum ist immer ein Innenraum," p. 37.

${ }^{41}$ Difford, "Infinite Horizons", pp. 304-305.

${ }^{42}$ Vidler, "Paris: Beistegui Apartment, Or Horizons Deferred", p. 275, p. 279.
} 
views only of four emblems of the "imperishable heritage" of Paris ${ }^{43}$ : the Arc de Triomphe, Sacré-Coeur, Notre Dame and the Eiffel Tower.

The intentions of the curious camera obscura pavilion are less self-evident than those of the chambre à ciel ouvert, but are potentially no less profound. The following tantalising hypothesis would, in a concrete way, couple Le Corbusier's thinking on the city of Paris with the diminutive pavilion. It hinges on Le Corbusier's familiarity with the symbolism traditionally attached to particular geometric figures. In this case, the figure is one that originated in Euclid's ancient epoch-making 13-book treatise on mathematics and geometry The Elements. The very first laconic proposition in the first book of The Elements reads as follows: "On a given finite straight line to construct an equilateral triangle" ${ }^{\text {"44 }}$. The ensuing sequence of geometric operations that can be carried out using a compass and straight edge arrive at a configuration of two circles whose centre points lie on the circumference of the other and on the common 'given finite straight line', creating an almond-shaped overlap (fig. 8). ${ }^{45}$ This figure at the centre of the composition is subsidiary to Euclid's geometrical proposition, but it later became invested with mystical significance in the cultural context of early Christianity, and became codified as a central Christian symbol in the medieval period. ${ }^{46}$ Coming to be known as the vesica piscis (fish bladder), it represented an opening and appearance of the divine, appearing most prominently in the West Façade of Chartres Cathedral (ca. 1145-55), where Christ is centrally situated in a vesica piscis shaped aureola in the central tympanum.

Le Corbusier was certainly familiar with the architecture of the Middle Ages, and he purported to be acquainted with the working methods, and 'secrets' of the masons who achieved the cathedrals. In When the Cathedrals Were White, 1937, he wrote that in the Middle Ages "the law of numbers was transmitted from mouth to mouth among initiates, after the exchange of secret signs" 47 . At that time "books did not yet exist. These rules of harmony are complicated, delicate. To understand the reason in them you have to have a spirit of some sensibility. Speak of them openly? That would be to put them in danger of errors of fact and of understanding" ${ }^{\text {. }}$. In the same year that the book was published, Le Corbusier installed a photomontage entitled L'Esprit de Paris in his Pavilion des Temps Nouveaux at the 1937 World Exposition (fig. 9). On the right hand side of this photomontage the medieval cathedral of Notre Dame de Paris is highlighted inside a clearly delineated vesica piscis form. A thin horizon line extends to the left of the vesica piscis, locating the top of the Arc de Triomphe and the base of the Panthéon.

Turning now to the form of the camera obscura pavilion, it can be revealed that the ground plan was determined geometrically by the vesica piscis configuration. And further that, when the plan of the pavilion is overlaid with

\footnotetext{
${ }^{43}$ Le Corbusier, The City of Tomorrow, p. 271, p. 281.

${ }^{44}$ Euclid, The Thirteen Books of the Elements. Vol. 1 (Introduction and Books I and II), New York: Dover, 1956, p. 241.

${ }^{45}$ The geometrical proof proceeds via the inscription of a circle that has its centre at Point A on one end of a 'given finite straight line' A-B, and a circumference that passes through Point B. A second circle of equal radius that has its centre at Point $\mathrm{B}$ is then inscribed, passing through Point $\mathrm{A}$. The centres of the circles are then joined to the point of intersection of the two circles, Point C, to create an equilateral triangle A-B-C.

${ }^{46}$ Note that Euclid became a venerated figure in operative stonemasonry, which is a craft driven by geometry. It is written in The Constitutions of Stonemasonry that “... all science lives only by the science of geometry... There is no tool to work with that has no proportion. And proportion is measure, and the tool or the instrument is earth. And geometry is... the measure of the earth, wherefore I may say that all men live by geometry... You shall understand that among all the crafts of the world... masonry has the most notability and most part of its science is geometry." The Constitutions of Masonry (ca. 1450, British Museum, M.S. 23198), ed. Matthew Cooke, London: R. Spencer, 1861.

${ }^{47}$ Le Corbusier, When the Cathedrals Were White [Quand les cathédrales étaient blanches, 1937], New York: McGraw-Hill, 1964, p. 6.

${ }^{48}$ Ibid., p. 6.
} 
Euclid's original geometric demonstration and with the L'Esprit de Paris montage (fig. 10), some striking correspondences are exposed. Notre Dame de Paris, one of the icons of the 'imperishable heritage' of Paris is central to the configuration. The Arc de Triomphe, another of the icons, appears to the left of the image, in the exact location that it would have appeared when viewed through the camera obscura periscope. ${ }^{49}$ The horizon line of the photomontage lies on the 'given finite straight line' of Euclid's geometric construction, emphasising the motif of 'horizon' that is persistent in Le Corbusier's architecture and his art. Peter Carl goes as far as to say that "it is difficult to find a painting of Le Corbusier in which the theme of the horizon does not appear" Malfroy also identifies a metaphorical assertion of the horizon in the Beistegui Apartment, particularly in respect to the camera obscura pavilion where: "on the periscope table one can read the ocean of the roofs of Paris or the desert of its walls" and further that the search is "no longer for the vertigo inducing altitude, rather it is for the aesthetic of the horizontal view: an aesthetic that had been communicated in the diorama that was exhibited in 1925 in the Pavillon de l'Esprit Nouveau" ${ }^{, 51}$. The image of the city projected down onto the small round table in the darkened camera obscura pavilion on the Champs-Elysée would never have the audacious profile of the Plan Voisin, but it captured the real Paris-the city of Le Corbusier's imagination.

\footnotetext{
${ }^{49}$ Note that in Le Corbusier's drawings the periscope is almost always drawn facing in the direction of the Arc de Triomphe and its location is often noted in annotations.

${ }^{50}$ Carl, "Le Corbusier's Penthouse in Paris", p. 67.

${ }^{51}$ Malfroy, "Der Aussenraum ist immer ein Innenraum," p. 39, p. 41.
} 


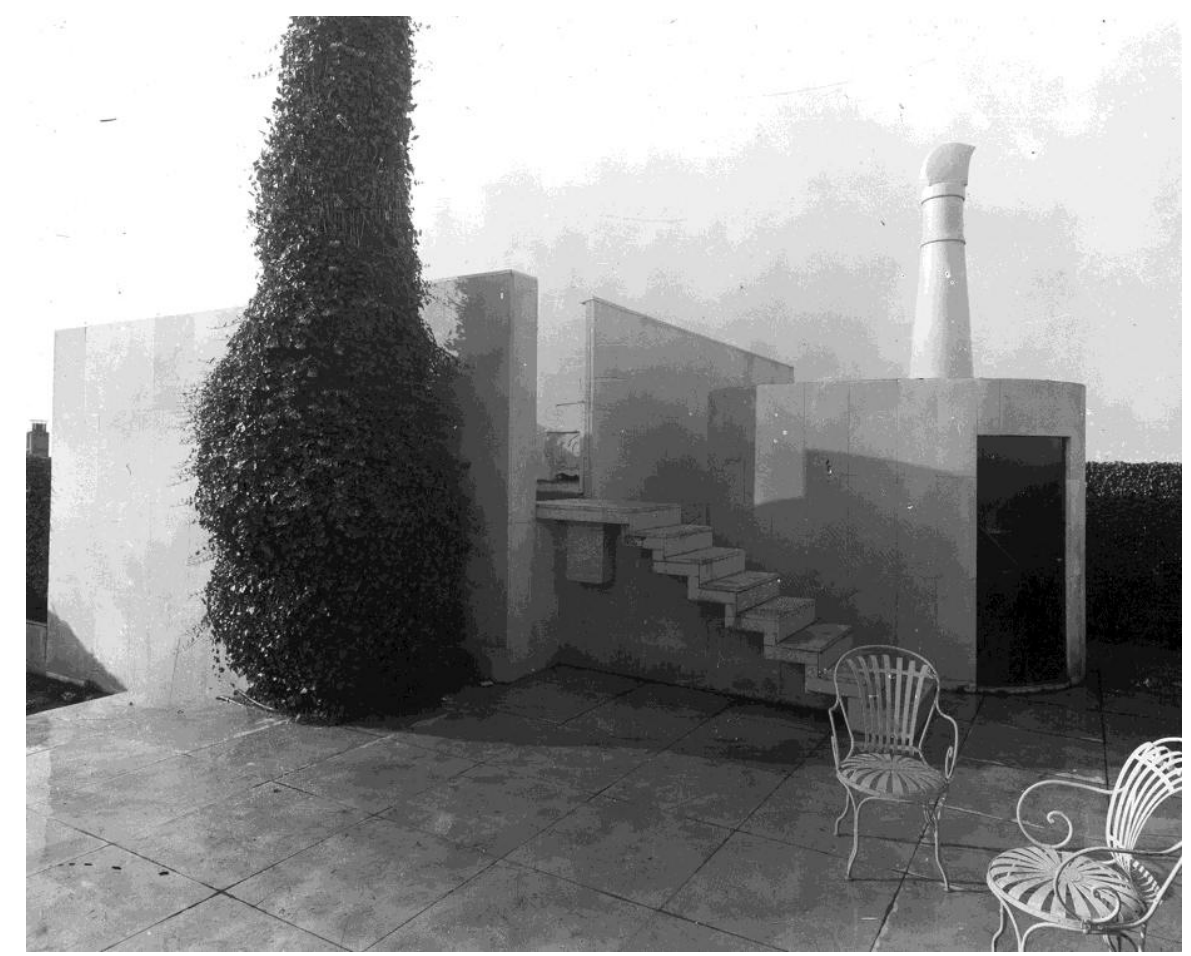

1. View of the camera obscura pavilion on the rooftop of the Beistegui Apartment (FLC L2-5-16 CFLC-ADAGP).

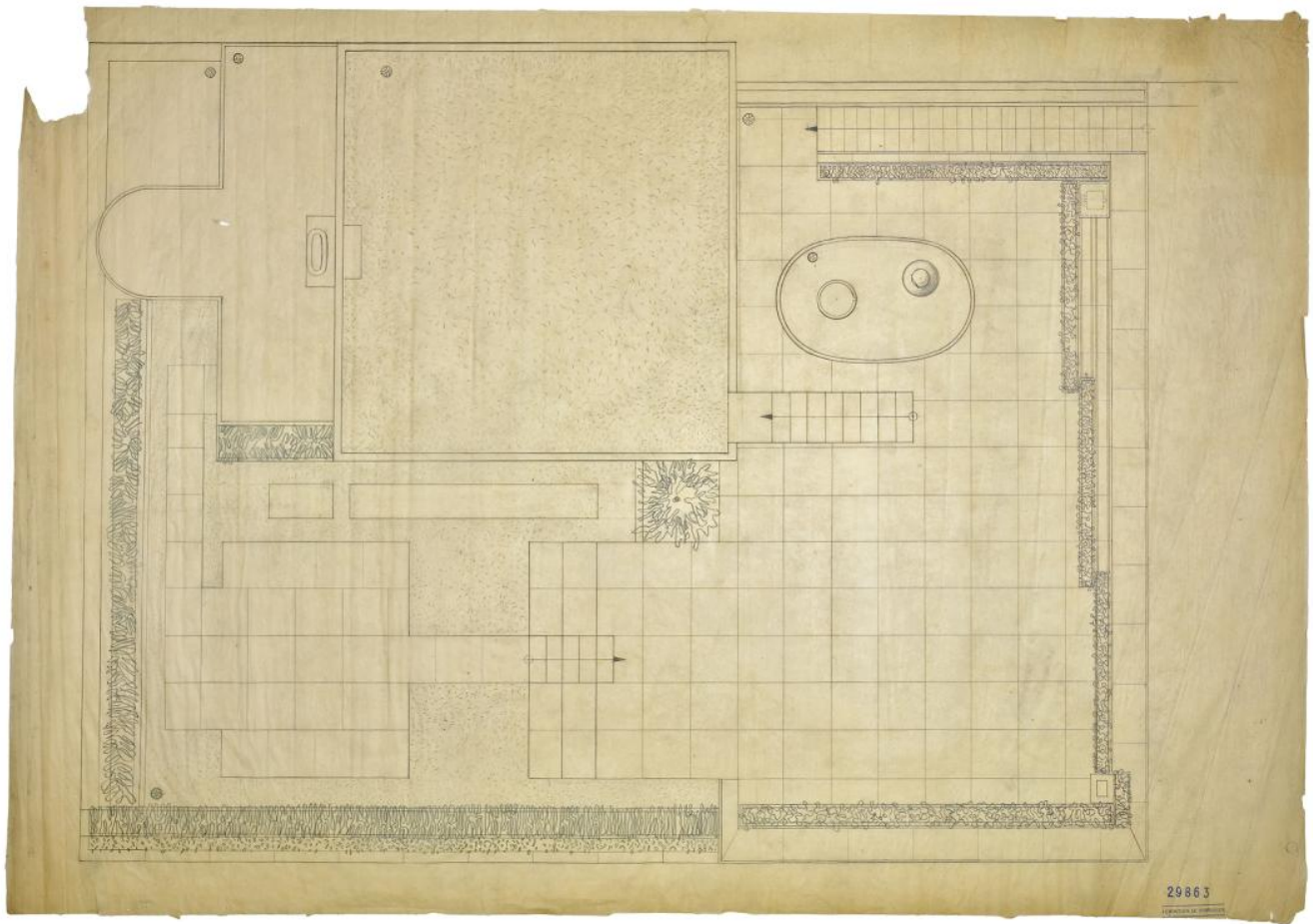

2. Final as built roof plan drawing of the Beistegui Apartment (FLC 29863 CFLC-ADAGP). 


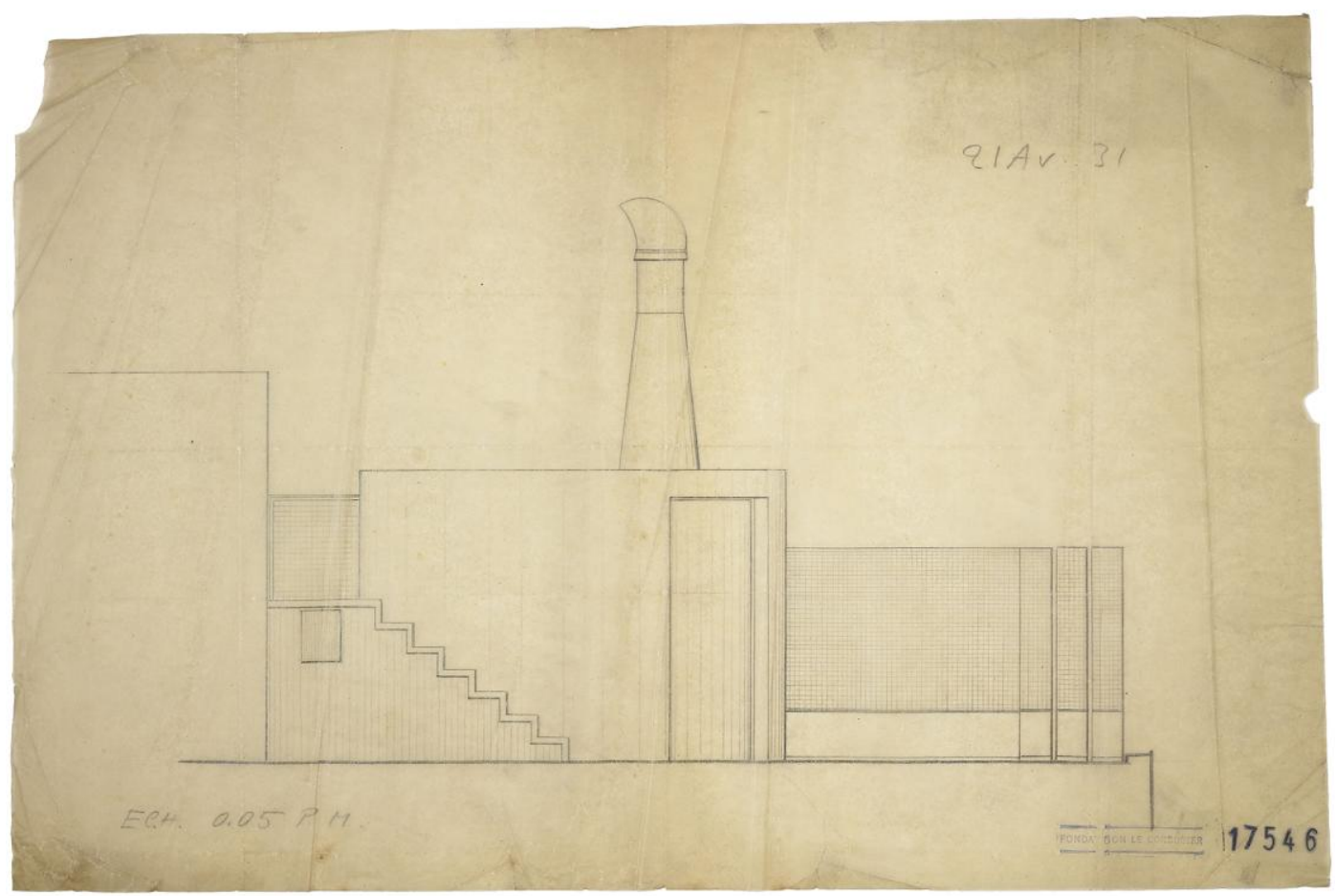

3. Elevation drawing of the camera obscura pavilion, $21^{\text {st }}$ April, 1931 (FLC 17546 OFLC-ADAGP).

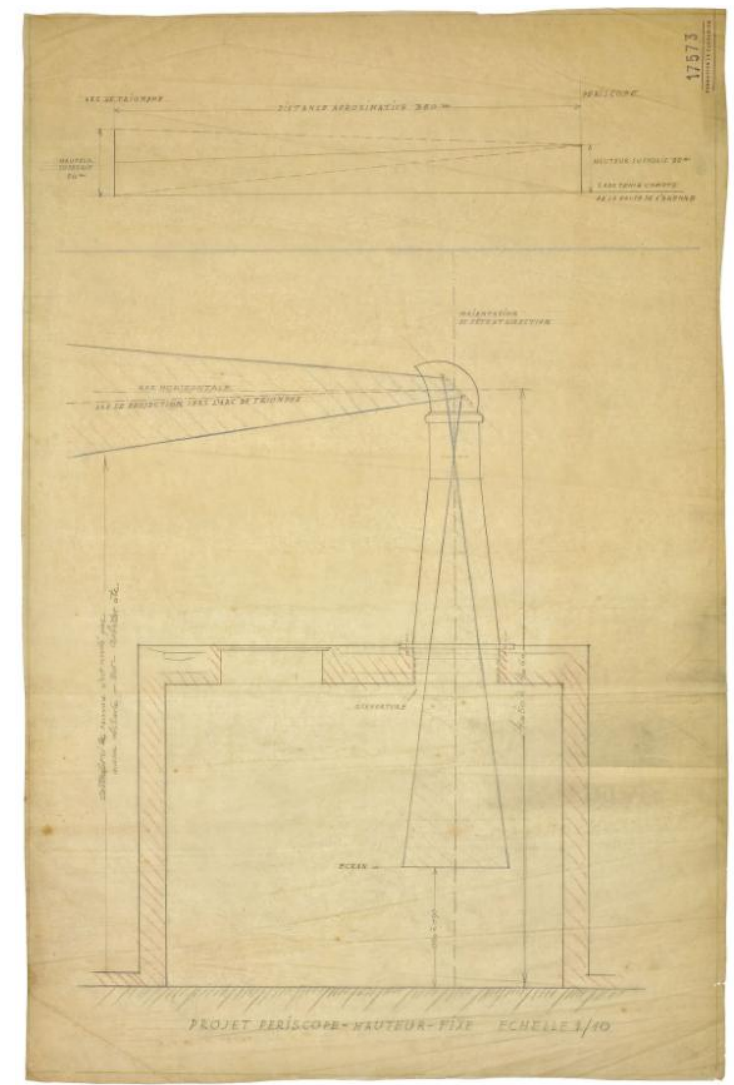

4. Section drawing of the camera obscura pavilion (FLC 17573 @FLC-ADAGP). 


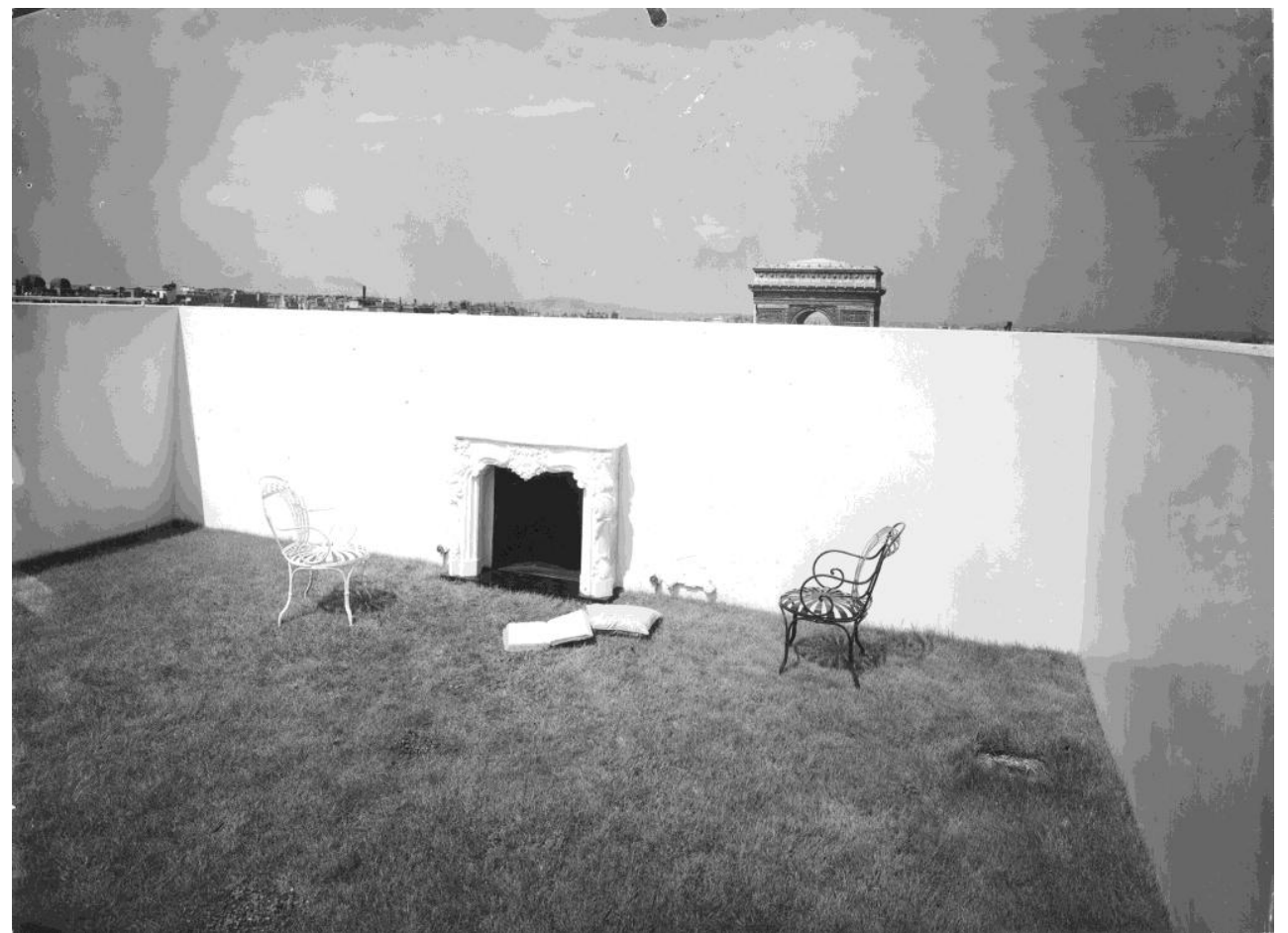

5. View of the fireplace in the chambre à ciel ouvert, with the Arc de Triomphe in the background (Photograph by Marius Gravot, FLC L2-5-23 (OFLC-ADAGP).

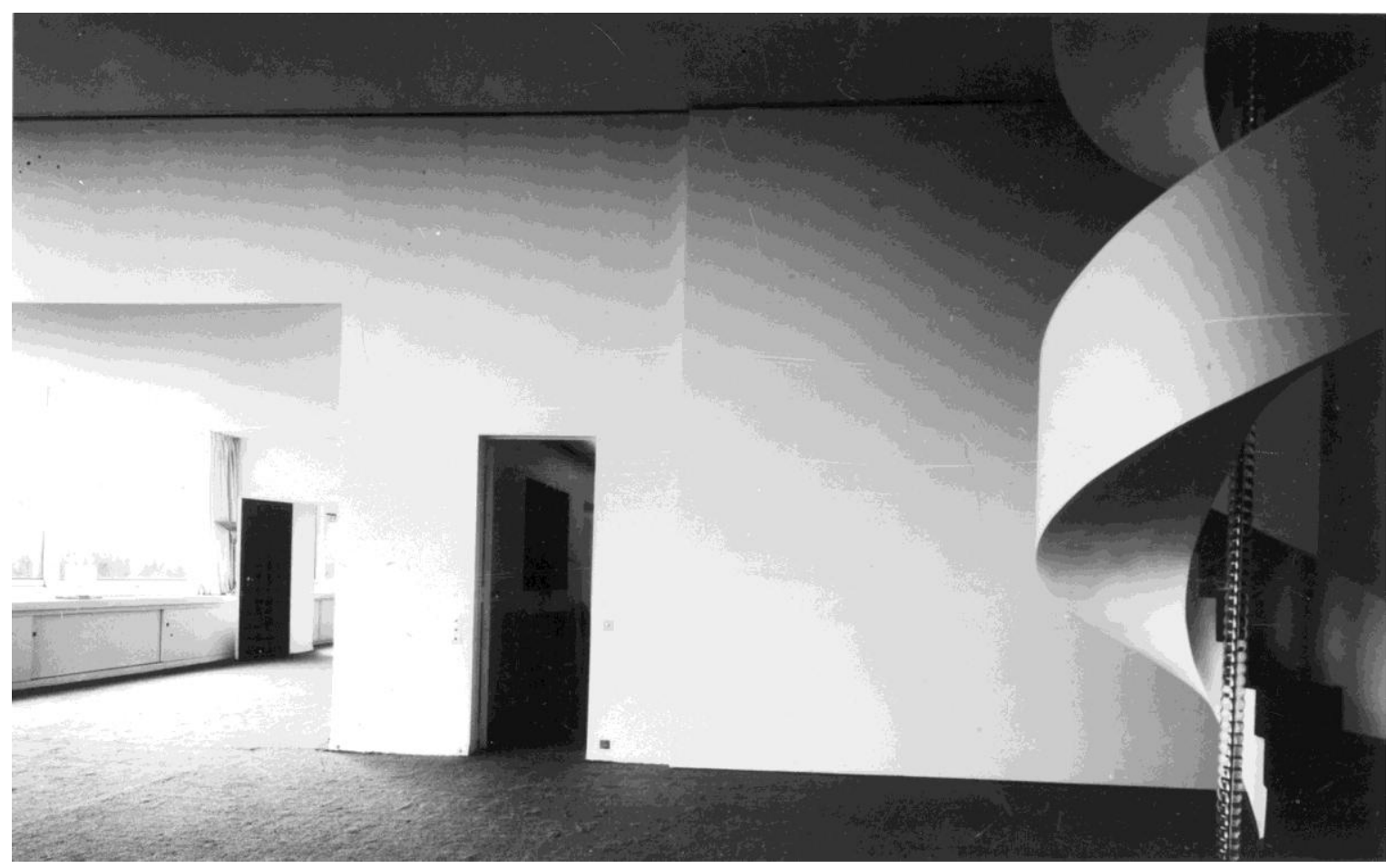

6. Interior view of the entertainment room, with the spiral staircase that arrives in the camera obscura pavilion (Photograph by Marius Gravot, FLC L2-5-37 (FLC-ADAGP). 

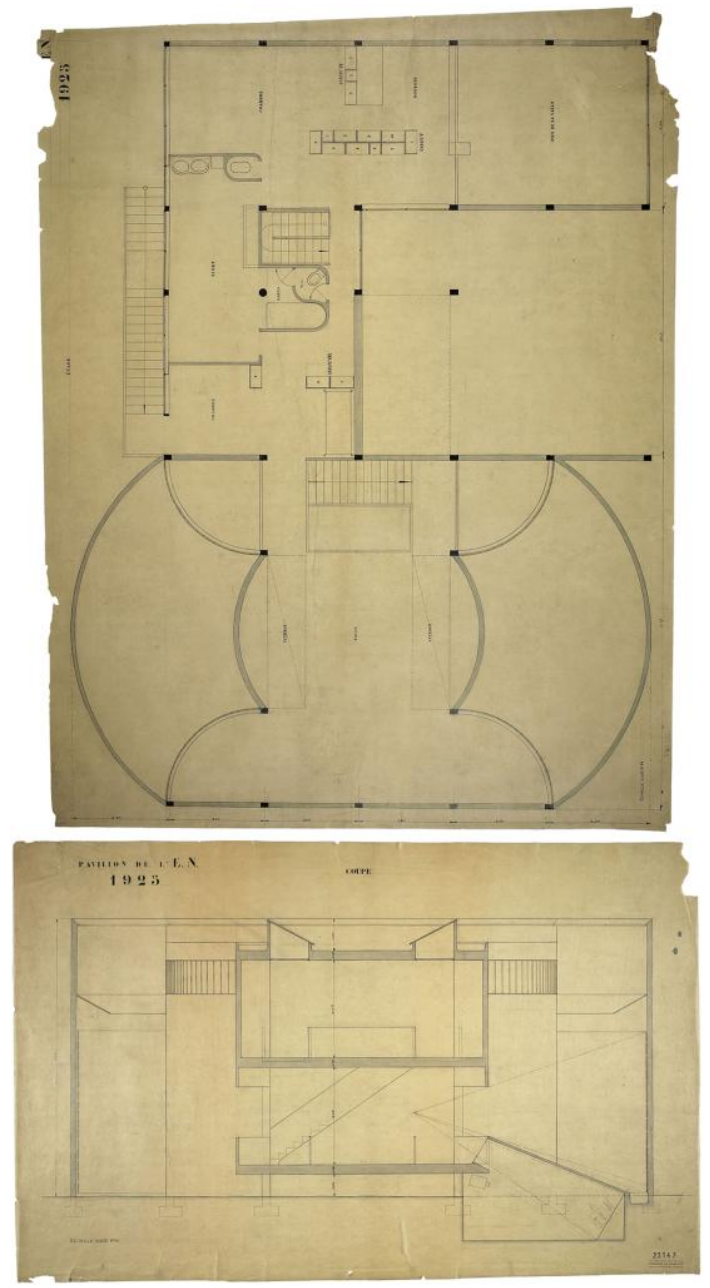

7. Plan and section drawings of the Pavillon de l'Esprit Nouveau at the International Exposition of Modern Decorative and Industrial Arts, Paris, 1925 (FLC 23132 and FLC 23147 OFLC-ADAGP).

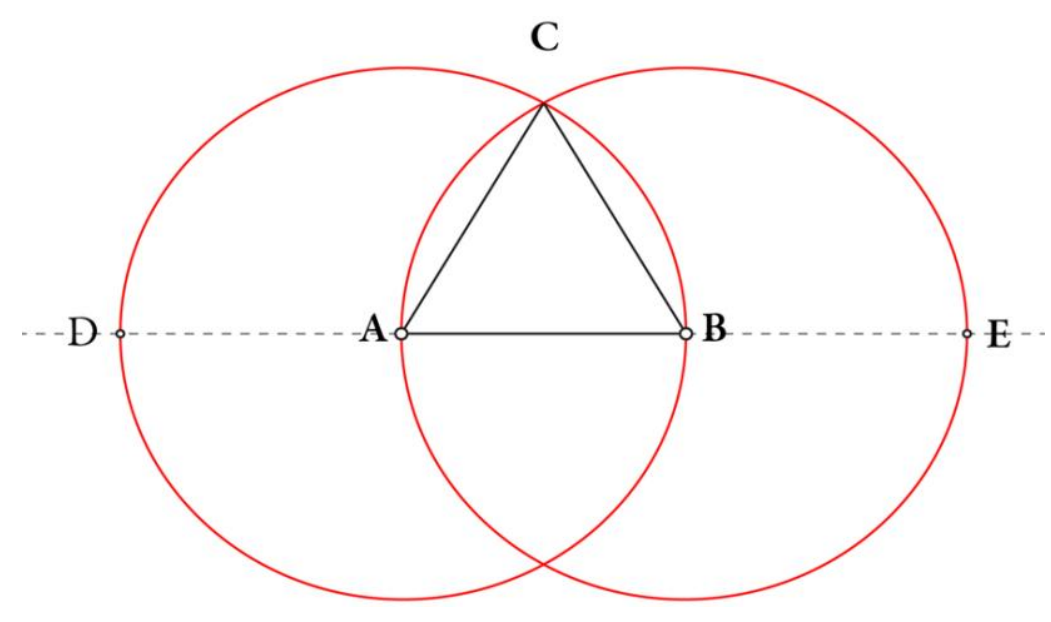

8. The geometrical proof of Euclid's first proposition in Book 1 of The Elements: "On a given finite straight line to construct an equilateral triangle." 


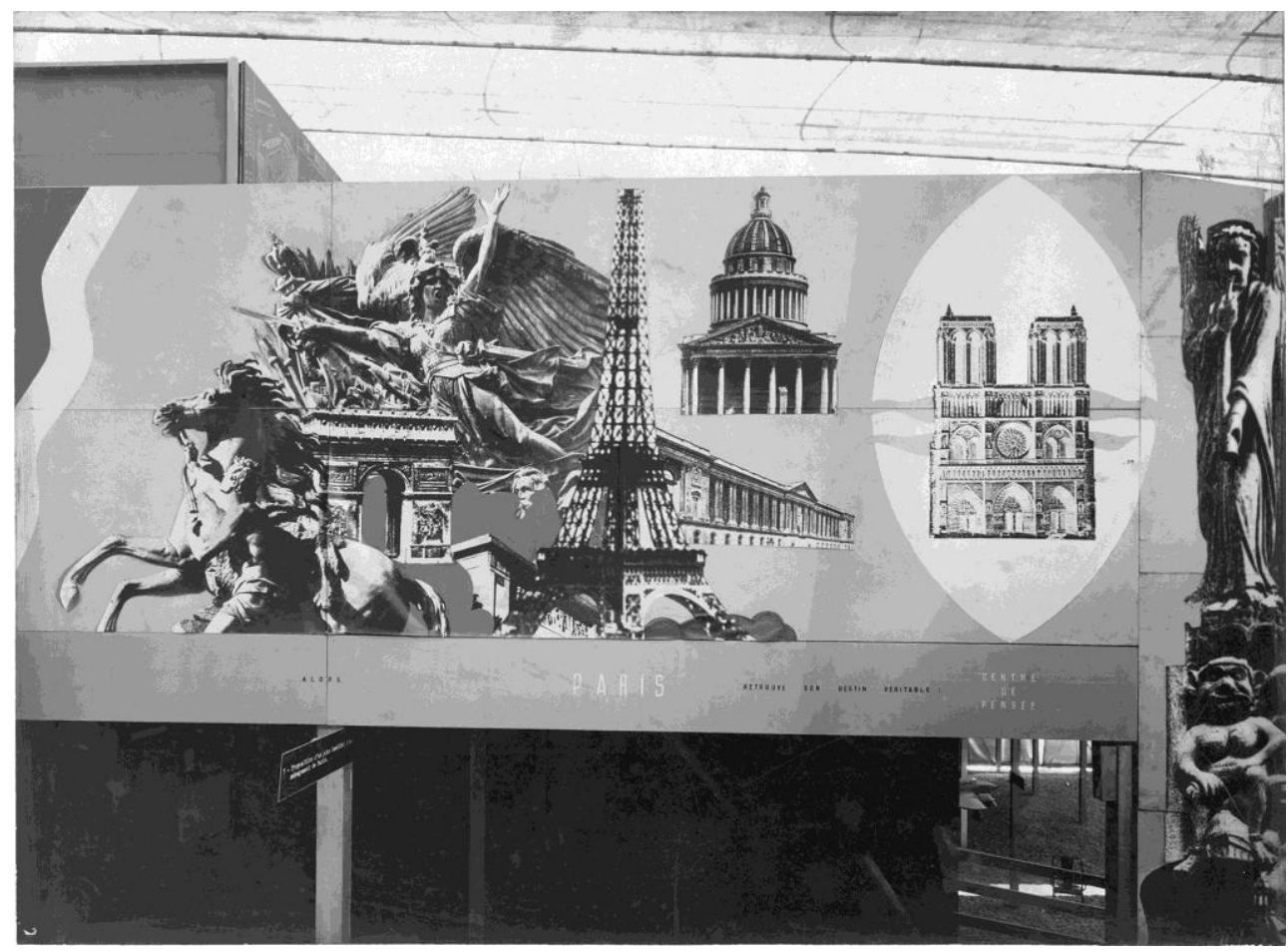

9. Le Corbusier's L'Esprit de Paris photomontage in his Pavilion des Temps Nouveaux at the 1937 World Exposition (Photograph by A. Salaün, FLC L2-13-109 OFLC-ADAGP).

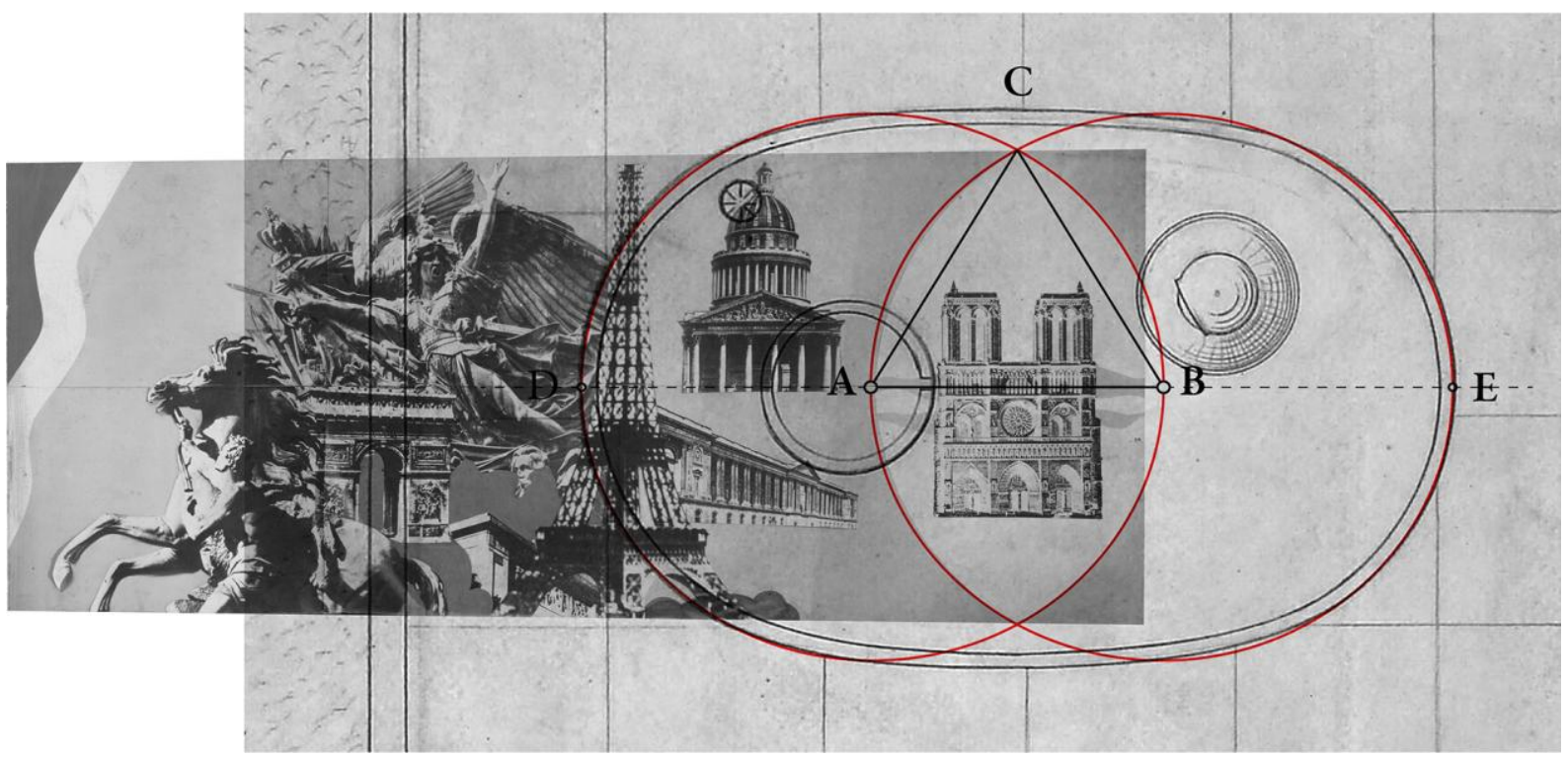

10. Composite image by the author that superimposes the roof plan of the camera obscura pavilion (FLC 29863, detail. CFLC-ADAGP) with the geometric figure of the vesica piscis, and with the L'Esprit de Paris photomontage (Photograph by A. Salaün, FLC L2-13-109 (FLC-ADAGP). 


\section{Bibliography}

Arizzoli-Clémentel, Pierre. Emilio Terry, 1890-1969: architecte et décorateur, Montreuil, France: Gourcuff Gradenigo, 2013.

Benjamin, Walter. "Surrealism: The Last Snapshot of the European Intelligentsia" [Der Sürrealismus. Die letzte Momentaufnahme der europäischen Intelligenz, 1929] in One-Way Street, London: Verso, 1979. pp. 225-39.

Benton, Tim. The Villas of Le Corbusier 1920-1930, Basel: Birkhäuser, 2007.

Bergdoll, Barry. "Paris: Le Corbusier and the Nineteenth-Century City" in Jean-Louis Cohen, ed., Le Corbusier: An Atlas of Modern Landscapes, New York: The Museum of Modern Art, 2012. pp. 246-49.

Bergh, Wim van den. "Charles Beistegui: Autobiography and Patronage" OASE 83 Commissioning Architecture, December 2010. pp. 17-40.

Boesiger, Willy. Le Corbusier et Pierre Jeanneret: Euvre complete, 1929-1934, Zurich: Girsberger, 1934.

Brooks, H. Allen, ed. The Le Corbusier Archive, Vol. II: Cité Frugès and Other Buildings and Projects 19231927, New York: Garland and Fondation Le Corbusier, 1983.

Brooks, H. Allen, ed. The Le Corbusier Archive, Vol VIII: Appartement de Beistegui, Cité Univérsitaire Pavillon Suisse, Ville Radieuse, and Other Buildings and Projects, 1930, New York: Garland and Fondation Le Corbusier, 1982.

Carl, Peter, “Le Corbusier's Penthouse in Paris, 24 Rue Nungesser-Et-coli,” Daidalos 28, June 1988. pp. 65-75.

Colomina, Beatriz, "The Split Wall: Domestic Voyeurism” in Max Risselada, ed. Raumplan Versus Plan Libre, New York: Rizzoli, 1988. pp. 32-51.

Conrads, Ulrich. ed. Programs and Manifestoes on $20^{\text {th }}$-century Architecture trans. Michael Bullock, Cambridge, Mass.: MIT Press, 1999.

Difford, Richard. "Infinite Horizons: Le Corbusier, the Pavilion De L'Esprit Nouveau Dioramas and the Science of Visual Distance," The Journal of Architecture 14:3, 2009. pp. 295-323.

Euclid, The Thirteen Books of the Elements. Vol. 1 (Introduction and Books I and II), 2nd ed., New York: Dover, 1956.

Freud, Sigmund. "The 'Uncanny" [Das Unheimliche, 1919] in The Complete Psychological Works, Vol. XVII, London: Hogarth Press 1955. pp. 217-56.

Gernsheim, Helmut and Alison Gernsheim, L. J. M. Daguerre: The History of the Diorama and the Daguerreotype, London: Secker \& Warburg, 1956.

Gorlin, Alexander. "The Ghost in the Machine: Surrealism in the Work of Le Corbusier", Perspecta 18, 1982. pp. $50-65$.

Hammond, John H. The Camera Obscura, Bristol: Adam Hilger, 1981.

Le Corbusier, The City of Tomorrow [Urbanisme, 1924], trans. Frederick Etchells, Cambridge, Mass.: MIT Press, 1929.

Le Corbusier, Towards a New Architecture [Vers une Architecture, 1923], trans. Frederick Etchells, London: J. Rodker, 1931.

Le Corbusier, When the Cathedrals Were White [Quand les cathédrales étaient blanches, 1937], New York: McGraw-Hill, 1964.

Lefèvre, Wolfgang. ed., Inside the Camera Obscura: Optics and Art under the Spell of the Projected Image, Max Planck Institute for the History of Science, 2007.

Lucan, Jacques Le Corbusier: une encyclopédie, Paris: Centre Georges Pompidou, 1987. pp. 68-71.

Malfroy, Sylvain “Der Aussenraum ist immer ein Innenraum," Werk, Bauen + Wohnen 81, 1994. pp. 36-41. 
Melis, Paolo. “Il 'cadavere squisito' di Le Corbusier: Pierre Jeanneret e Charles Bestegui”, Controspazio 9, no. 3, 1977. pp. 36-37.

Porta, Giambattista della. Natural Magick by John Baptista Porta, a Neapolitane: In Twenty Books: Wherein are Set Forth all the Riches and Delights of the Natural Sciences [Magia Naturalis, 1558], London: Thomas Young \& Samuel Speed, 1658.

Saddy, Pierre. "Le Corbusier Chez Les Riches, L’appartement De Beistegui," Architecture, Mouvement, Continuité 49, 1979. pp. 55-70.

Tafuri, Manfredo. "The City in the Work of Le Corbusier" in H. Allen Brooks, ed., Le Corbusier, Princeton, NJ: Princeton University Press, 1987. pp. 203-218.

Vesely, Dalibor. Architecture in the Age of Divided Representation: The Question of Creativity in the Shadow of Production, Cambridge, Mass.: MIT Press, 2004.

Vesely, Dalibor. "Architecture and the Ambiguity of Fragment" in Robin Middleton, ed., The Idea of the City, Cambridge, Mass.: MIT Press, 1996. pp. 108-21.

Vesely, Dalibor. "Surrealism, Myth and Modernity”, AD Profiles 11, 1978. pp. 87-95.

Vidler, Anthony. "Fantasy, The Uncanny and Surrealist Theories of Architecture" Papers of Surrealism 1, Winter 2003.

Vidler, Anthony. "Paris: Beistegui Apartment, Or Horizons Deferred" in Jean-Louis Cohen, ed., Le Corbusier: An Atlas of Modern Landscapes, New York: The Museum of Modern Art, 2013. pp. 274-79.

Vidler, Anthony. The Architectural Uncanny, Cambridge, Mass.: MIT Press, 1992. 